\title{
Pollination compatibility of Dendrobium spp. orchids from Bali, Indonesia, and the effects of adding organic matters on seed germination under in vitro culture
}

\author{
IDA AYU PUTRI DARMAWATI ${ }^{1, \boldsymbol{v}}$, IDA AYU ASTARINI ${ }^{2}$, HESTIN YUSWANTI ${ }^{1}$, YUYUN FITRIANI ${ }^{1}$ \\ ${ }^{1}$ Program of Agroecotechnology, Faculty of Agriculture, Universitas Udayana. Jl. Raya Kampus Unud, Bukit Jimbaran, Kuta Selatan, Badung 803611, \\ Bali, Indonesia. Tel./fax.: +62-361-702801, "email: darmawati@unud.ac.id \\ ${ }^{2}$ Department of Biology, Faculty of Mathematics and Natural Sciences, Universitas Udayana. Jl. Raya Kampus Unud, Bukit Jimbaran, Kuta Selatan, \\ Badung 803611, Bali, Indonesia.
}

Manuscript received: 19 February 2021. Revision accepted: 14 April 2021

\begin{abstract}
Darmawati IAP, Astarini IA, Yuswanti H, Fitriani Y. 2021. Conservation of Dendrobium spp. Bali orchids (Indonesia) through in vitro seed culture. Biodiversitas 22: 2554-2559. Orchid species, including Dendrobium spp., originated from Bali are threatened to extinction due to habitat destruction, illegal hunting, small population size, and the effects of global environmental change. Conservation strategies are therefore required to preserve the remaining germplasm, one of which is through in vitro seed propagation. This research aimed to investigate the pollination compatibility (i.e., pollination that produce fruits) of Dendrobium orchids originated from Bali, and to determine the effects of adding organic matters (i.e., coconut water, tomato extract, and peptone) to the base media on orchid seed germination under in vitro culture condition. Self-pollination and sibling pollination were implemented to seven orchid species, namely Dendrobium macrophyllum, D. heterocarpum, D. fimbriatum, D. linearifolium, D. spathilingue, D. secundum, and D. plicatile. The results showed that only four species, i.e., D. macrophyllum, D. heterocarpum, D. fimbriatum, and $D$. linearifolium, that produced fruits after being pollinated. The subsequent in vitro propagation of seeds produced by the four species showed that the addition of organic matters of tomato extract, coconut water, and peptone significantly affected the germination of Dendrobium forma Bali orchid seeds, indicated by different germination rates. The addition of $20 \%$ coconut water to Vacin and Went (VW) media gave the highest percentages of seed germination and protocorm formation for D. macrophyllum, D. heterocarpum, and D. fimbriatum at $98.33 \%$ and $95.00 \%$; $91.67 \%$ and $91.67 \%$; and $95 \%$ and $98.33 \%$, respectively. Our findings can serve as baseline information when developing conservation strategies of Dendrobium orchids from Bali, particularly from the aspect of propagation.
\end{abstract}

Keywords: Compatibility, pollination, propagation, organic matters

\section{INTRODUCTION}

Dendrobium is among orchid species with the largest diversity in the world, totaling of approximately 1,600 species, and is widespread from Southeast Asia to Australia (De et al. 2015). The name 'Dendrobium' is derived from 'dendron' which means tree and "bios" means 'life', implying that this is an epiphytic plant that grows by clinging to the branches and trunks of host trees (Pradhan et al. 2013). Many orchid species from this genus have the potentials as the breeding source of ornamental flower hybrids, either as cut flowers or potted plants, as well as prospective to be used for medicinal purposes (Teixeira da Silva et al. 2014). Thus, Dendrobium orchids are important from the perspective of economic.

Despite the economic potentials, nowadays the existence of Dendrobium orchids is threatened by various causes, including habitat destruction, illegal hunting, small population size, and the effects of global environmental change (Darmawati et al. 2018). According to Widiatmoko (2017), plant diversity in Indonesia is facing an increasingly serious threat of extinction, where 437 species are threatened with extinction, and even more than 600 species if the Near Threatened category is included, this condition positions Indonesia as one of the highest priorities for global plant conservation. For this reason, Indonesia needs to immediately develop an effective strategy to conserve plants at risk of extinction. Such threatening processes can put the orchid into extinction, suggesting that immediate conservation actions are urgently needed. One of the conservation strategies is by conserving the genetic resources of native Dendrobium orchid species, especially those that occur in areas with high anthropological and environmental pressures (Fay 2018).

Among the regions with geographical distribution of Dendrobium orchids is Bali, Indonesia. Yet, Bali is increasingly pressured by human factors, particularly due to the development of tourism sector. A study by Darmawati et al. (2018) found 24 species of Dendrobium in a forest area in Bali. Several species of Dendrobium forma Bali that have been explored are very potential to be selected as parental species in hybridization based on the character of the flower, such as the uniqueness of shape, color, and size, for example, Dendrobium macrophyllum A. Rich. (jamrud orchid, pastor's orchid), D. secundum (Blume) Lindl (toothbrush orchid) and D. heterocarpum Wall. ex Lindl (fountain orchid), D. crumenatum Sw., D. 
fimbriatum Hook, D. linearifolium Teijsm. \& Binn, D. spathilingue J.J. Sm., and D. plicatile Lind.

In the context of orchid conservation in Bali, conservation strategies in the form of in-situ and ex-situ conservations are necessary to preserve the genetic diversity or orchid to prevent them from extinction. In-situ conservation means conserving biodiversity entities (e.g. orchid plants) in their natural habitats, such as national parks, nature reserves, and protection forests (Hou et al. 2012; Merritt et al. 2014). Meanwhile, ex-situ conservation means conserving biodiversity outside their natural habitat, and is commonly conducted by transporting and putting them into a new location, such as botanic gardens, germplasm banks either conventionally or using tissue culture (in vitro culture), including seed bank development, slow growth conservation and cryopreservation of seed, meristem, tissue-cultured shoot primordia, somatic embryos, and pollen.

In this modern era, in vitro cultivation techniques are viable alternatives for the germination and production of orchid seedlings in a short period (Salazar and Botello, 2020). The advantage of in vitro culture is that it produces a large number of identical seeds in a relatively short time that have almost the same properties as the parent. Specific media for seed germination of some orchids have been widely reported (Lesar et al. 2012; Piri et al. 2013; Jualang et al. 2014; Shekarriz et al. 2014; Utami et al. 2015; Wida et al. 2017; Salazar and Botello 2020). The composition of the media and the use of plant growth regulator (PGR) are critical factors that determine the success of the implementation of in vitro culture. Plant growth regulators can be sourced from organic and synthetic materials. The use of synthetic PGR sometimes causes mutations in orchids, for example, orchid growth that tends to be stunted (Gusta et al. 2011). This mutation is undesirable in the collection of genetic resources, so in this research, asymbiotic germination used VW media (Vacin \& Went, 1949) without the use of ZPT, but organic materials, such as coconut water, tomatoes, and peptone.

This research aimed to investigate the pollination compatibility (i.e., pollination that produce fruits) of seven species of Dendrobium orchids originated from Bali, and to determine the effects of adding organic matters (i.e., coconut water, tomato extract, and peptone) with varying concentrations to the base media on orchid seed germination under in vitro culture condition. In this study, the seeds of Dendrobium forma Bali orchid were obtained through self-pollination and sibling pollination.

\section{MATERIALS AND METHODS}

\section{Pollination of Dendrobium forma Bali}

Plant specimens of seven species of Dendrobium, namely Dendrobium macrophyllum, D. heterocarpum, D. fimbriatum, D. linearifolium, D. spathilingue, $D$. secundum, and D. plicatile, were collected from the exploration of several forests in Bali (Darmawati et al. 2018). Each individual plant was in healthy condition and was in bloom. Pollination was conducted on orchids that were in full bloom from day 0 to day 6 after blooming from August 2019 to August 2020. Pollination was conducted in the morning from 07.00 to 10.00 on 1 or 2 flowering individuals. Pollinia were transferred from the anther to the stigma using a sterile toothpick by the following methods: (i) Self-pollination (selfing): pollinia are transferred into the stigma of one flower in one plant (ii) sibling pollination (intercrossing): pollinia are transferred into the stigma between two different flowers in one plant. After pollination was conducted, fruit development, fruit drop, and fruit ripening were observed regularly. The successful pollination is marked by the swelling of the flower stalk, which then develops into a fruit. The variables observed in the pollination stage were the percentages of fruit development, fruit drop, and physiologically ripe fruit. Furthermore, the ripe fruit, which was physiologically characterized by a brighter, slightly yellowish skin color and a wider line on the fruit, were ready to be harvested.

\section{Sterilization of orchid fruit explants}

After the orchid fruits were harvested, then they were washed with detergent and rinsed with running water until they were clean. The useless part of the fruit was discarded. The explant sterilization was conducted in Laminar Air Flow Cabinet (LAFC). The fruit was dipped in $70 \%$ alcohol and then baked over a bunsen lamp. This activity was repeated three times. The disinfection and sowing of the seeds were carried out according to the methodology described by (Darmawati 2019).

\section{Media for planting and seed germination}

The basic culture media used in this study were instant Vacin and Went (VW) media. To make 1 liter of VW medium, $1.67 \mathrm{~g}$ of instant $\mathrm{VW}, 20 \mathrm{~g}$ of sugar, and $7 \mathrm{~g}$ of agar were put into a $1000 \mathrm{ml}$ beaker. In this research, we investigated the effects of adding three substances with varying concentrations (factors of treatment) on germination and formation of protocorm of the orchids observed. The three factors were tomato extract (i.e., 0, 50, $100,150$ and $200 \mathrm{ml} / \mathrm{L})$; coconut water $(50,100,150$ and $200 \mathrm{ml} / \mathrm{L}$ ); and peptone (1, 2 and $3 \mathrm{~g} / \mathrm{L})$. Each treatment on the media was repeated 3 times, so that there were 36 experimental units.

The tomato juice (TJ) from mature red tomato of "Intan" variety from Bali and coconut water $(\mathrm{CW})$ from mature yellow coconut (in Bali it is called "Kelapa Gading") (Dwiyani et al. 2015). Then, sterile distilled water was added to reach the 1-liter mark and stirred until well blended. After that, $\mathrm{pH}$ was adjusted to 5.8. If it was less than 5.8, the $\mathrm{NaOH}$ was added, whereas if it was higher than 5.8, then HCL was added. The medium was poured into a sterile culture bottle and covered with plastic and tightened with a rubber band. The medium was sterilized by autoclave at a temperature of $121^{\circ} \mathrm{C}$ and a pressure of 17.5 psi for 20 minutes. The explants were implanted in LAFC under sterile conditions. The fruit was placed in a petri dish and with a sterile blade, the fruit was cut into 2 pieces (Darmawati 2019). Each part was split with a scalpel, then the orchid seeds were sprinkled on a bottle containing the planting medium using tweezers. 
Furthermore, the culture bottles were stored on the culture rack in the maintenance room. The culture room temperature was maintained at $23^{\circ} \mathrm{C} \pm 2{ }^{\circ} \mathrm{C}$. The lighting in the room was fluorescent lamp with a power of 20 Watt for each shelf. The variables observed during in vitro culture were the time when each stage of orchid seed germination occurred and when protocorms were formed.

\section{Data analysis}

Pollination result data are presented in the form of percentage of successful fruit set, fruit ripening time, and fruit size and color, which are then discussed descriptively. Meanwhile, data on the effect of media on Dendrobium orchid seed germination were analyzed statistically by Analysis of Variance (ANOVA). If there is a treatment that shows a significant effect, the 5\% Duncan's test will be conducted on that treatment.

\section{RESULTS AND DISCUSSION}

\section{Percentage of successful pollination}

The percentage of successful pollination was determined by counting the fruits formed from the total number of flowers crossed. Pollination is more successful if it was conducted a day to two days during the peak bloom or in the first week to the fifth week since the flowers bloom. Pollination success occurs when pollinarium can be put into rostellum. The percentage of successful pollination is presented in Table 1 .

Plants are said to be compatible if fertilization occurs after pollination. Compatible pollination occurs because there is compatibility between the pistil and pollen so that the fruit is formed. Based on Table 1, D. spathilingue, D. plicatile, and D. secundum were not able to produce fruit. According to Pershina and Trubacheeva (2017) incompatible pollination can be caused by incompatibility between male and female parts. This incompatibility is controlled by environmental, genetic, and physiological factors. In natural mechanisms, incompatibility occurs when the pollen tube growth is so slow that it never reaches the ovules. The incompatibility which emerges before fertilization is defined as prezygotic incompatibility, i.e., the inability to cross, whereas the incompatibility which emerges after fertilization is defined as postzygotic (Pershina and Trubacheeva 2017).

Fruit ripening rate varied depending on the species of orchids, for example, D. macrophyllum had \pm 109 days after transplanting, D. heterocarpum had \pm 105 days after transplanting, $D$. fimbriatum had \pm 100 days after transplanting, and D. linearifolium had \pm 66 days after transplanting (Table 1). Determination of the right and optimum harvesting age greatly affects seed dormancy period. The observed fruit shape and size in this research showed varied results (Table 2 and Figure 1). The shape of the fruit is controlled by the female parent while the size of the fruit is determined by the availability of nutrients in the media and the ability of the leaves to provide photosynthate.

\section{The effect of organic matters on germination}

Based on the ANOVA results, the addition of organic matters of tomato, coconut water, and peptone extracts had a significant effect on Dendrobium spp. forma Bali orchid seed germination (Table 3). These results are in accordance with the statement by Arditti (1992), that the addition of organic matters in tissue culture media had an effect on orchid seed germination, except for $D$. linearifolium seed culture, which had fungal contamination. The advantages of adding organic matter into the basic medium for seed germination of orchids have also been reported by other studies, for example in Dendrobium Alya pink (Nambiar et al. 2012), Vanda tricolor forma Bali (Dwiyani et al. 2015), Vanda helvola (Murhayati et al. 2015), Laeliocattleya hybrid (Salazar and Botello 2020).

Table 1. The results of pollination success, pollination compatibility and harvesting age of Dendrobium forma Bali orchids

\begin{tabular}{lcccc}
\hline $\begin{array}{c}\text { Dendrobium orchid } \\
\text { species }\end{array}$ & $\begin{array}{c}\text { Pollination } \\
\text { frequency }\end{array}$ & $\begin{array}{c}\text { Percentage of successful } \\
\text { pollination }(\boldsymbol{\%})\end{array}$ & $\begin{array}{c}\text { Compatibility rate } \\
(\%)\end{array}$ & $\begin{array}{c}\text { Harvesting age (days after } \\
\text { transplanting) }\end{array}$ \\
\hline D. macrophyllum & 4 & 100 & 100 & 109 \\
D. heterocarpum & 2 & 100 & 100 & 105 \\
D. fimbriatum & 2 & 100 & 100 & 100 \\
D. linearifolium & 2 & 50 & 50 & 66 \\
D. spathilingue & 4 & 0 & 0 & - \\
D. plicatile & 2 & 0 & 0 & - \\
D. secundum & 3 & 0 & 0 & - \\
\hline
\end{tabular}

Table 2. Average length and diameter and color of fruit resulted from the pollinations of Dendrobium forma Bali orchids

\begin{tabular}{lccl}
\hline \multicolumn{1}{c}{ Dendrobium species } & $\begin{array}{c}\text { Average length of fruit } \\
(\mathbf{c m})\end{array}$ & $\begin{array}{c}\text { Average diameter of } \\
\text { fruit }(\mathbf{c m})\end{array}$ & $\begin{array}{c}\text { Fruit color } \\
\text { (RHS color chart) }\end{array}$ \\
\hline D. macrophyllum & 5.03 & 2.37 & Brilliant yellowish green \\
D. heterocarpum & 4.40 & 1.77 & Vivid yellowish green \\
D. fimbriatum & 5.85 & 1.15 & Brilliant yellowish green \\
D.lineariforium & 1.80 & 1.19 & Light yellowish green \\
\hline
\end{tabular}




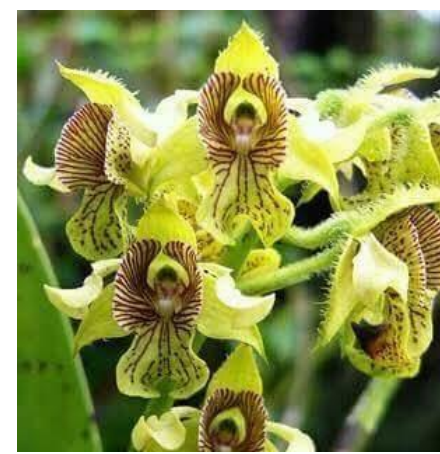

A

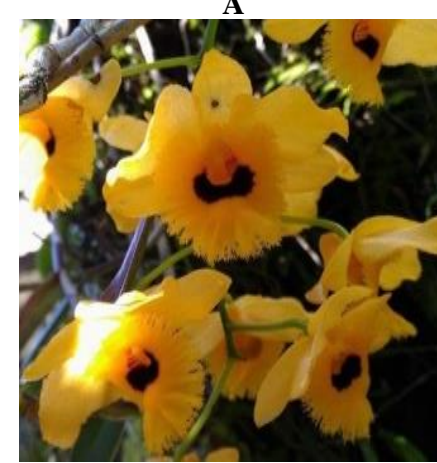

$\mathbf{E}$

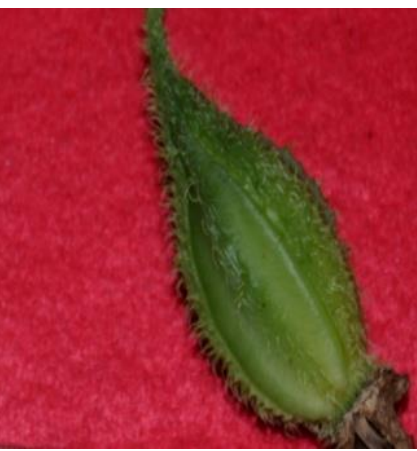

B

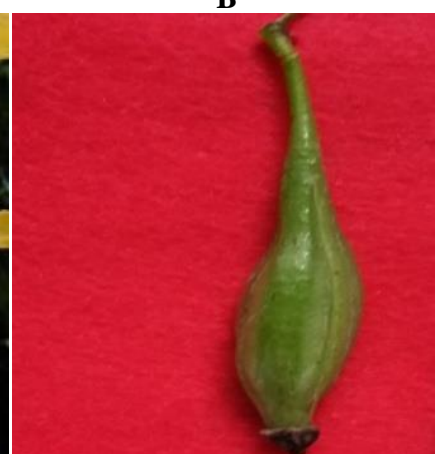

$\mathbf{F}$

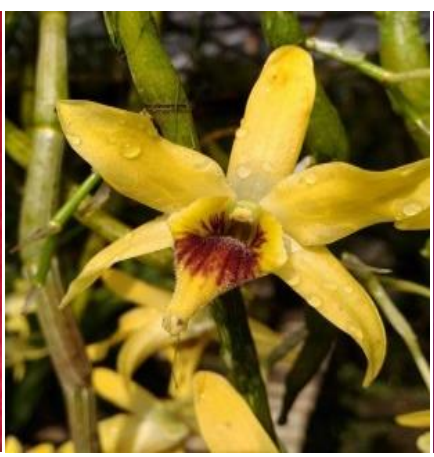

C

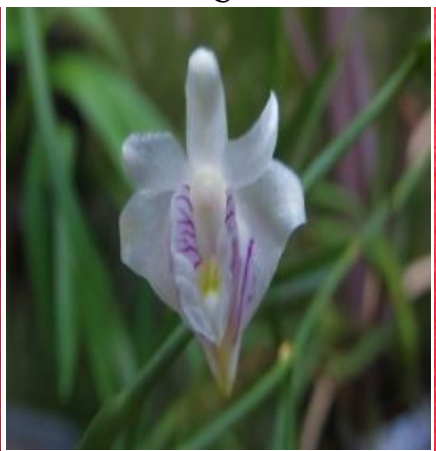

G

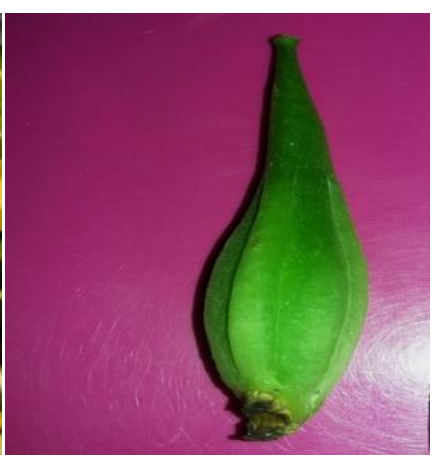

D

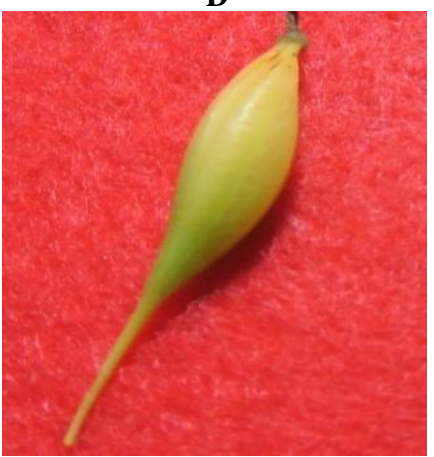

$\mathbf{H}$

Figure 1. The flower and fruit of four species of Dendrobium orchids forma Bali: D. macrophyllum (A and B); D. heterocarpum (C and D); D. fimbriatum (E and F); and D. linearifolium ( $\mathrm{G}$ and $\mathrm{H})$.

Table 3. The effect of addition of organic matters in VW media on seed germination and formation of protocorm of Dendrobium forma Bali orchids

\begin{tabular}{|c|c|c|c|c|c|c|c|}
\hline \multirow{2}{*}{ Organic substance } & \multirow{2}{*}{ Concentration } & \multicolumn{2}{|c|}{ D. macrophyllum } & \multicolumn{2}{|c|}{ D. heterocarpum } & \multicolumn{2}{|c|}{ D. fimbriatum } \\
\hline & & A & B & A & B & A & B \\
\hline Tomato extract & 0 & $21.67 \mathrm{f}$ & $16.67 \mathrm{e}$ & $18.33 \mathrm{f}$ & $21.67 \mathrm{~d}$ & $15.00 \mathrm{f}$ & $18.33 \mathrm{f}$ \\
\hline \multirow{4}{*}{$(\% . \mathrm{V} / \mathrm{v})$} & 5 & $25.00 \mathrm{f}$ & $20.00 \mathrm{e}$ & $21.67 \mathrm{f}$ & $21.67 \mathrm{~d}$ & $18.33 \mathrm{f}$ & 23.33 ef \\
\hline & 10 & $31.67 \mathrm{def}$ & $23.33 \mathrm{e}$ & $25.00 \mathrm{~d}$ & $25.00 \mathrm{~d}$ & 23.33ef & $26.67 \mathrm{ef}$ \\
\hline & 15 & $46.67 \mathrm{~d}$ & $33.33 \mathrm{~d}$ & $36.67 \mathrm{c}$ & $36.67 \mathrm{c}$ & $43.33 d$ & $43.33 \mathrm{~d}$ \\
\hline & 20 & $75.00 \mathrm{bc}$ & $75.00 \mathrm{~b}$ & $73.33 b$ & $73.33 b$ & $75.00 \mathrm{c}$ & $73.33 \mathrm{bc}$ \\
\hline \multirow[t]{4}{*}{ Coconut water $(\%, v / v)$} & 5 & $85.00 \mathrm{ab}$ & $78.00 \mathrm{~b}$ & $75.00 \mathrm{~b}$ & $75.00 \mathrm{~b}$ & $83.33 \mathrm{ab}$ & $83.33 \mathrm{ab}$ \\
\hline & 10 & $88.33 \mathrm{ab}$ & $81.00 \mathrm{a}$ & $78.33 b$ & $78.33 b$ & $86.67 \mathrm{ab}$ & $86.67 \mathrm{ab}$ \\
\hline & 15 & $91.67 \mathrm{a}$ & $90.00 \mathrm{a}$ & $86.67 \mathrm{a}$ & $86.67 \mathrm{a}$ & $86.67 \mathrm{ab}$ & $86.67 \mathrm{ab}$ \\
\hline & 20 & $98.33 \mathrm{a}$ & $95.00 \mathrm{a}$ & $91.67 \mathrm{a}$ & $91.67 \mathrm{a}$ & $95.00 \mathrm{a}$ & $98.33 \mathrm{a}$ \\
\hline Peptone & 0.1 & $26.67 \mathrm{ef}$ & $23.33 \mathrm{e}$ & $23.33 \mathrm{f}$ & $23.33 \mathrm{~d}$ & 23.33ef & $25.00 \mathrm{ef}$ \\
\hline \multirow[t]{2}{*}{$(\%, \mathrm{w} / \mathrm{v})$} & 0.2 & $41.67 \mathrm{de}$ & $33.33 \mathrm{~d}$ & $30.00 \mathrm{ef}$ & $30.00 \mathrm{~d}$ & $38.33 d$ & $38.33 \mathrm{de}$ \\
\hline & 0.3 & $65.00 \mathrm{c}$ & $45.00 \mathrm{c}$ & $41.67 d$ & $35.00 \mathrm{c}$ & $41.67 \mathrm{~d}$ & $63.33 \mathrm{c}$ \\
\hline Mean & 51.25 & 51.25 & 58.06 & 49.58 & 49.86 & 50.83 & 55.56 \\
\hline Min. & 10 & 10 & 10 & 10 & 20 & 5 & 10 \\
\hline Max. & 95 & 95 & 100 & 95 & 95 & 95 & 100 \\
\hline SD & 29.602 & 29.602 & 28.990 & 27.630 & 27.736 & 29.580 & 29.442 \\
\hline
\end{tabular}

Note: The mean number followed by different letters shows a significant difference according to Duncan's test $(\alpha=0.05)$. A: seed germination, B: formation of protocorm. SD: standard deviation

The success of orchid seed germination is influenced by several factors, such as fruit ripening, base medium, and the addition of organic matter (Gnasekaran et al. 2012; Parthibhan et al. 2012; Setiari et al. 2016; Salazar and Botello 2020). In this research, the addition of tomato extract to the VW base media showed a lower percentage of seed germination and protocorms formation compared to the addition of coconut water (Table 3). This result is in line with the research of Nambiar et al. (2012), but different from the research of Dwiyani et al. (2015) and Salazar and Botello (2020), which showed that $150 \mathrm{~g} / \mathrm{l}$ tomato extract was able to grow more Vanda tricolor forma 
Bali embryos than the same control on Vanda helvola (Murhayati et al. 2015). In Salasar and Botello (2020), the addition of pineapple juice showed the best growth of Laeliocattleya Richard Muller asymbiotic germination (56 $\pm 2.8 \%)$ and in seedlings formation $(25.8 \pm 0.8)$ compared to coconut water. All data above indicate that the need for types of organic additives for growth of orchid seedlings is species-specific.

Tomato extract contains vitamin $\mathrm{C}$ which can stimulate organogenesis, somatic embryogenesis, and shoot growth in micropropagation of various plant species (Dwiyani et al. 2015). According to Singh and Deen (2014) tomatoes also contain allelopathic compounds, namely tomatin, which is inhibitory and lethal. The low percentage of seed germination of Dendrobium orchids forma Bali on media with tomato extract addition was probably due to the inhibitory effect of tomatin compound. In addition, the different responses of these different species might be due to different inhibitors for germination of the embryos of each species. These inhibitors will affect the activation of the enzymes that initiate the germination and growth process.

Based on Table 2, $0.3 \%$ peptone showed a significant difference on the variable of germination percentage compared to the control, but showed no significant difference with $20 \%$ tomato extract. Peptone is able to induce germination and growth of orchid seeds because it contains substances such as ammonium nitrogen, aspartic acid, glycine amide nitrogen, and amino acids (Shekarriz et al. 2014), which play a role in seed germination.
The $20 \%$ coconut water in VW base media resulted in the highest percentages of seed germination and protocorm formation in D. macrophyllum, D. heterocarpum, and D. fimbriatum, with $98.33 \%$ and $95.00 \%$ (21 days after sowing/DAS and 124 DAS); 91.67\% and 91.67\% (35 DAS and 138 DAS); $95 \%$ and $98.33 \%$ (28 DAS and 130 DAS), respectively. The difference in the timing of seed germination and formation of protocorms is due to the different embryos of each species, so that they show different responses to the treatment.

Coconut water is liquid endosperm of coconut (Cocos nucifera L.) which contains soluble sugars as a natural source of carbon, amino acids, phenols, fiber, and vitamins. In addition, coconut water also contains diphenyl urea that functions as a cytokinin, which can increase explant growth and regeneration by inducing cell division (Winarto et al. 2015; Texeira da Silva et al. 2015). Coconut water was found to be beneficial for seed germination of Dendrobium Alya Pink (Nambiar et al. 2012), Phalaenopsis hybrid'Manchester'(Shekarriz et al. 2014), Dendrobium antennatum (Wida and Hariyanto 2016), and an endemic orchids Rhynchostylis retusa (Nisha Raj 2017).

The development of orchid embryos was maintained until 124 DAS (Dendrobium macrophyllum), 138 DAS (D. heterocarpum), and 130 DAS (D. fimbriatum), then subcultured on shoot-and-root induction media with the addition of some base media and growth regulators, such as auxins and cytokinins. The development stage of Dendrobium orchid seeds until protocorm formation is presented in Figure 2.

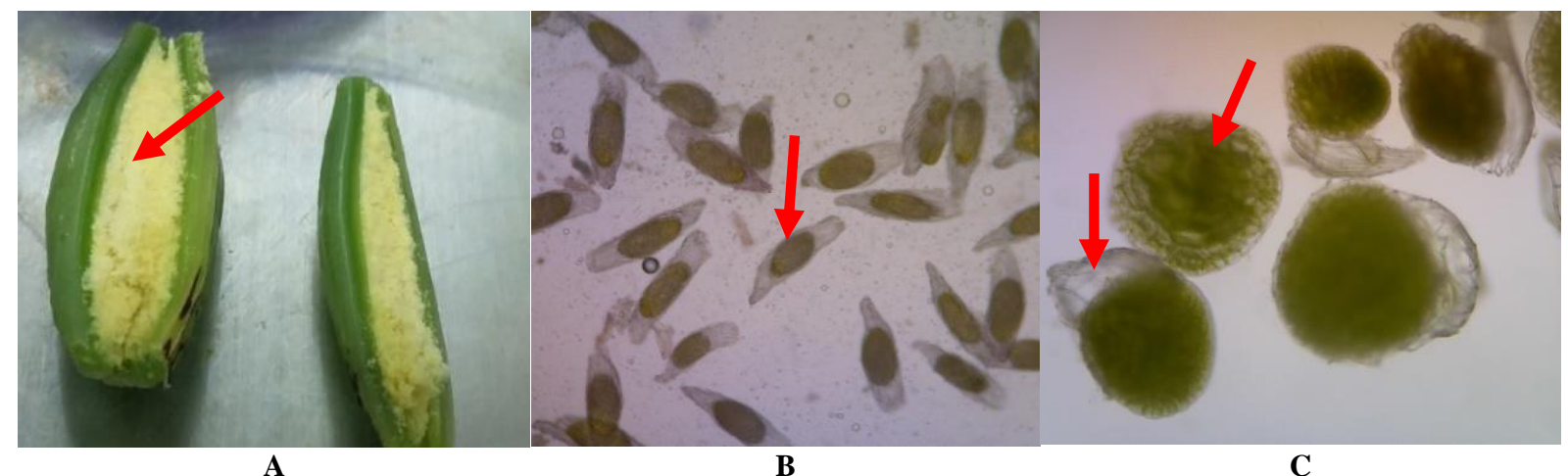

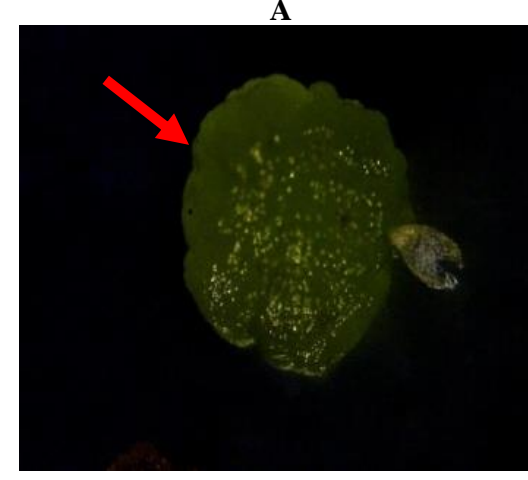

D

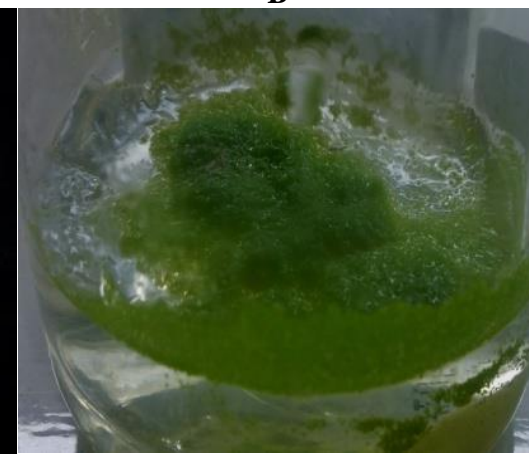

$\mathbf{E}$

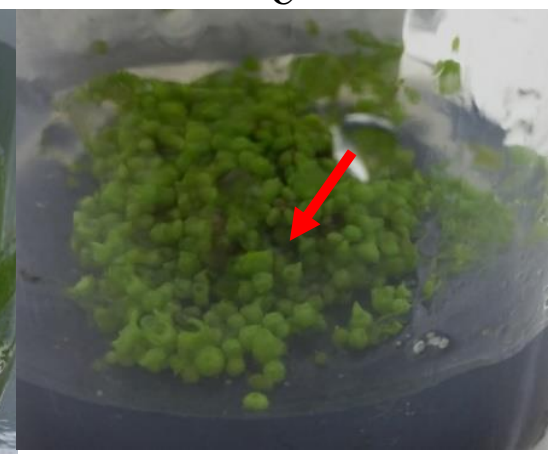

$\mathbf{F}$

Figure 2. Seed developmental stages of Dendrobium forma Bali orchids: A) Physiologically ripe orchid seeds (indicated by arrow); B) development of orchid seeds seven days after sowing (DAS); C) Enlarged embryos that broke through the testa 14 DAS; D-E) Protocorm stage 124 DAS; F) Protocorms that had been subcultured on shoot-and-root induction media (arrows indicate leaf primordia) 
In conclusion, among seven species of Dendrobium forma Bali we found only four species that had pollination compatibility (i.e., pollination that produces fruits) with the highest percentage was found in D. macrophyllum, $D$. fimbriatum, D. heterocarpum, and the lowest were in $D$. linearifolium. The addition of organic matters of tomato extract, coconut water, and peptone significantly affected seed germination of Dendrobium orchids from Bali, indicated by different germination rates. The addition of $20 \%$ coconut water to Vacin and Went (VW) media gave the highest percentages of sprout and protocorm formation for $D$. macrophyllum, D. heterocarpum, and D. fimbriatum. These findings enrich the existing knowledge in the theme of in vitro propagation in orchids with our study adding the context of seven species of Dendrobium originated from Bali.

\section{ACKNOWLEDGEMENTS}

We thank Udayana University, Bali, Indonesia for the funding provided through Budget Implementation Entry List on Non-tax Revenue (DIPA PNPB) with the issuance of Research Assignment Contract Number B/20171/UN14.4.A/LT/2020, dated March 10, 2020.

\section{REFERENCES}

Darmawati IAP, Rai IN, Dwiyani R, Astarini IA. 2018. Short Communication: The diversity of wild Dendrobium (Orchidaceae) in Central Bali, Indonesia. Biodiversitas 19 (3): 1110-1116. DOI: 10.13057/biodiv/d190345.

Darmawati IAP. 2019. Exploration and Characterization of PhenotypicGenothypic Dendrobium Orchid forma Bali and Evaluation of it Hybrid Compatibility. [Dissertation]. Udayana University, Bali. [Indonesian]

De LC, Rao AN, Rajeevan PK, Srivastava M. 2015. Morphological characterization in Dendrobium species. J Biosci 4 (1): 1198-1215.

Dwiyani R, Yuswanti H, Darmawati IAP, Suada K, Mayadewi NNA. 2015. In vitro germination and its subsequent growth of an orchids Vanda tricolor Lindl. var. suavis from Bali on complex additives enriched medium. Agrivita J Agric Sci 37 (2): 144-150. DOI: 10.17503 /agrivita.v37i2.497.

Fay MF. 2018. Orchid conservation: How can we meet the challenges in the twenty-first century? Rev Bot Stud 59 (16): 2-6. DOI: 10.1186/s40529-018-0232-z.

Gnasekaran P, Poobathy R, Mahmood M, Samian MR, Subramaniam S. 2012. Effects of complex organic additives on improving the growth of PLBs of Vanda Kasem's Delight. Aust J Crop Sci 6: 1245-1248.

Gusta AR, Hapsoro D, Sa'diyah N, Yusnita. 2011. Pengaruh media dasar dan benziladenin (BA) terhadap pembesaran seedling anggrek Dendrobium in vitro. Jurnal Agrotropika 16 (2): 76-79. [Indonesian]

Hou B, Tian M, Luo J, Ji Y, Xue Q, Ding X .2012. Genetic diversity assessment and ex situ conservation strategy of the endangered Dendrobium officinale (Orchidaceae) using new trinucleotide microsatellite markers. Plant Syst Evol 298: 1483-1491. DOI 10.1007/s00606.012-0651-3.

Teixeira da Silva JA, Zeng SJ, Galdiano JrRF, Dobranszki J, Cardoso JC, Vendram WA. 2014. In vitro conservation of Dendrobium germplasm. Plant Cell Rep 33: 1413-1423. DOI 10.1007/s00299-0141631-6.

Jualang AG, Devina D, Hartinie M, Sharon, Roslina J. 2014. Asymbiotic seeds germination and seedlings development of Vanda dearei. Malaysian Appl Biol 43 (2): 25-33.
Lesar H, Nataša C, Damijana K, Zlata L. 2012. Asymbiotic seed germination of Phalenopsis L. Blume orchids after hand pollination. Acta Agriculturae Slovenica 99 (1): 5-11. DOI: 10.5897/ajar11.1145.

Merritt DJ, Hay FR, Swarts ND, Sommerville KD, Dixon KW.2 014. Exsitu conservation and cryopreservation of orchid germplasm. Intl $\mathrm{J}$ Plant Sci 175: 46-58. DOI: 10.1086/673370.

Murharyati Y, Defiani MR, Astiti NPA. 2015. Pertumbuhan anggrek Vanda helvola pada media yang diperkaya jus tomat. Jurnal Metamorfosa 2 (2): 66-71. DOI: 10.24843/metamorfosa.2020.v07.i02 [Indonesian]

Nambiar N, Tee CS, Maziah M. 2012. Effects of organic additives and different carbohydrate sources on proliferation of protocorm-like bodies in 'Dendrobium' Alya Pink. Plant Omics 5 (1): 10-18.

Nisha Raj S. 2017. Effect of coconut water and activated charcoal on seed germination in an endemic orchids Rhynchostylis retusa Blume. Kong Res J 4 (2): 147-150. DOI: 10.26524/krj215.

Parthibhan S, Benjamin JHF, Muthukumar M, Sherif NA, Kumar TS, Rao MV. 2012. Influence of nutritional media and photoperiods on in vitro asymbiotic seed germination and seedling development of Dendrobium aqueum Lindley. J Plant Sci 6 (14): 383-393. DOI: 10.5897/AJPS12.132.

Pershina LA, NV Trubacheeva. 2017. Interspecific incompatibility in wide hybridization of plants and ways to overcome. Russian J Genet Appl Res 7 (4) : 416-425. DOI: 10.18699/VJ16.082.

Piri H, Pathak P, Bhanwara RK. 2013. Asymbiotic germination of immature embryos of a medicinally important epiphytic orchid Acampe papilosa (Lindl) Lindl. Afr J Biotechnol 12: 172-167.

Pradhan S, Paudel YP, Pant B. 2013. Efficient regeneration of plants from shoot tip explants of Dendrobium densiflorum Lindl., a medicinal $\begin{array}{llll}\text { orchid. Afr J Biotechnol } 12 & \text { (12): 1378-1383. DOI: }\end{array}$ 10.5897/AJB12.2731.

Salazar SAM, Botello EAD. 2020. Effect of the medium composition on the asymbiotic germination and in vitro development of the Laeliocattleya hybrid. S Afr J Bot 135: 80-86. DOI: 10.1016/j.sajb.2020.08.

Setiari N, Aziz P, Sukarti M, Semiarti E. 2016. Peptone and tomato extract induced early stage of embryo development of Dendrobium Phalaenopsis orchids. J Trop Biodiv Biotechnol 1 (2): 77-84. DOI: 10.22146/jtbb. 15498 .

Shekarriz P, Mohsen K, Shirin DD, Masoud M. 2014. Coconut water and peptone improve seed germination and protocorm-like body formation of hybrid Phalaenopsis. Agric Sci Develop 3 (10): 317 322.

Singh NB, Deen S. 2014. Allelopathic potential of ferulic acid on tomato. Tunisian J Plant Protect 9 (1): 1-9.

Teixeira da Silva JA, Dobránszki J, Cardoso JC, Zeng SJ. 2015. Dendrobium micropropagation: A review. Plant Cell Rep. DOI: 1007/s00299-015-1754-4.

Utami ESW, Purnobasuki H, Soedart T, Heriyanto S. 2015. Asymbiotic seed germination and in vitro seedling development of Paphiopedilum liemianum Fowlie, an endangered terrestrial orchid in Sumatra, Indonesia. J Plant Sci 10 (1): 25-34. DOI: 10:3923/jps.

Vacin EF, Went FW. 1949. Use of tomato juice in the symbiotic germination of orchid seeds. Bot Gaz 111 (2): 174-183.

Wida ESU, Hariyanto S, Wulan YSM. 2017. In vitro propagation of the endangered medicinal orchid, Dendrobium lasianthera J. J. Sm through mature seed culture. Asian Pacific J Trop Biomed 7 (5): 406410. DOI: 10.1016/j.apjtb.2017.01.011.

Wida ESU, Hariyanto S. 2016. The effect of organic nutrient and growth regulators on seed germination, embryo and shoots development of Dendrobium antennatum by in vitro. J Biosaintifika 8 (2): 165-171 DOI: $10.15294 /$ biosaintifika.v8i2.5165.

Widiatmoko D. 2017. Conservation of Indonesian Plant Diversity: A Case Study of Threatened Plant Conservation in the Botanic Gardens. Proceedings of the 2017 Osaka City University International Symposium: Symbiosis of People and Plants for the Future of the City. Osaka City University and Osaka Museum of Natural History, Osaka, Japan.

Winarto B, Jaime A, da Silva T. 2015. Use of coconut water and fertilizer for in vitro proliferation and plantlet production of Dendrobium 'Gradita 31'. In Vitro Cell Dev Biol Plant 51: 303-314. DOI $10.1007 / \mathrm{s} 11627-015-9683-\mathrm{z}$. 